Aleksandar S. Santrač ${ }^{1}$

North-West University, South Africa

Greenwich School of Theology, United Kingdom

Chesapeake Conference, Maryland, USA

alex.santrac@gmail.com

DOI: 10.18485/rit.2021.19.36.3
UDK: $128 / 129$

$27-186$

Origanalni naučni rad

Datum prijema: 16.06.2021.

\title{
UNCERTAINTY AND DEATH - INEVITABILITY, UNIVERSALITY AND IRREVERSIBILITY OF DEATH -
}

\begin{abstract}
Summary
The main purpose of this article is to present the uncertainty of death as a possible bridge between secular and Christian understanding of death reality. The article describes death in all its philosophical aspects juxtaposing it to the Christian brief synopsis at the end.
\end{abstract}

Key words: death, Christianity, uncertainity, despair, fear, Holy scriptes

\section{Introduction}

The main challenge with death is not that it is inevitable. Everyone is aware that sooner or later our mortality will be materialized in a cessation of physical existence. No religion or philosophy entirely denies the reality of termination of life. The dilemma is that death comes unexpectedly every time because there is no natural death. Death is death because it is always an unexpected and unwelcoming intrusion into life. Death is a phenomenon that contradicts the nature of life. Every death creates anxiety and uncertainty, and every death is unnatural. Simone de Beauvoir, the French feminist existentialist, asserts: 'There is no such thing as a natural death: nothing that happens to a man is ever natural since his presence calls the world into question' (Beauvoir in Cutter 2019: 132). Every death is

1 Aleksandar (Alex) S. Santrac, DPhil (University of Belgrade, Serbia), PhD (NorthWest University, South Africa), $\mathrm{PhD}$ (Education) (cand.) (Notre Dame of Maryland University) is Lead Pastor of the Chesapeake Conference, Columbia, MD; Extraordinary Researcher and Professor of Dogmatics and Dogma and Church History at the Unit for Reformation Theology and Advancement of South African Society, North-West University, South Africa; Online Tutor for Graduate Studies in Dogmatics, Philosophy, and Ethics at the Greenwich School of Theology, UK and Theological University of Apeldoorn, NL; Member Representative of the Seventh-Day Adventist Church (Observer), Faith and Order Commission, National Council of Churches; Member of the Ethics Committee, Washington Adventist Hospital. 
an unexpected mystery because life is a mystery. Our presence in this world is a great puzzle, and existentially it is unrepeatable and unique. Death is a significant loss of the fantastic secret of life.

Thinking about the reality of death brings us to the universality of death. It is a human reality. We all share this unique experience. That is why the study of death is essential for our self-understanding, self-exploration, and 'reflection upon what it means to be human' (Cutter 2019: 1). The exploration of death helps us to live our lives differently, to reaffirm or reinvent our fundamental human values. The study of the nature of death and the familiar question of what is beyond death help us penetrate into the deepest realm of the meaning of life. For that reason, investigation of the reality of death has captivated human minds from the beginning of civilization.

The philosopher Cody Gilmore, in his essay 'When do things die?' affirms the fact that death is both permanent and irreversible (Gilmore 2013: 18-19). The impossibility of living again, though there are a few contemporary theories contrary to this, makes humans fearful and uncertain of the unknown, since death is irreversible. Dying becomes a painful journey towards the cessation of life that will never again reappear. Inevitably, we experience the complete disintegration of life in death.

\section{Physical, Psychological and Moral Disintegration in Death}

There are several aspects of disintegration. First of all, death is physical disintegration. Both Aristotle and Descartes affirmed that death is a loss of physical matter (Cutter 2019: 18). Death can be defined as '(1) irreversible cessation of circulation and respiratory functions, or (2) irreversible cessation of all functions of the entire brain, including the brain stem' (President's Commission 1981: 2). There is much discussion in bioethics about determining a brain-oriented definition of death (see Belking 2003: 325-361), but the scope of this essay does not allow me to discuss details. Mortality is the result of the primary biological/physical disintegration.

Moreover, the discussion over the nature of death before or after total brain failure has led some ethicists and philosophers to speak about psychological disintegration in death, namely, cessation of all mental activity of the whole person. The first discussion of this sort was launched by John Locke, a famous empiricist philosopher, who explained that self is primarily consciousness. Our self is present through consciousness, not through biological functions of the brain or the body (Gordon-Roth 2020). Death, therefore, would be the cessation of all our psychological capacities that make up the fabric of our personality. 
Finally, death can be defined as the moral disintegration of the personality. Fred Feldman tries to explain that death is the cessation of being a person. If personality is a moral concept, when people die their moral right to life is gone, and their personhood defined in moral terms exists no more (Felman 2013: 60-79). In other words, in death the moral idea and reality of the person are gone.

Death, therefore, is the complete and irreversible cessation of biological, psychological, and moral functions of the personality.

\section{Death and Despair}

For Danish philosopher Søren Kierkegaard (1813-1855), death is a complex phenomenon, and it determines the mental state of the person. He says: 'When death is the greatest danger, one hopes for life. But, when one becomes acquainted with an even more dreadful danger, one hopes for death. So when the danger is so great that death has become one's hope, despair is the disconsolateness of not being able to die' (Kierkegaard 1849). Despair makes human beings mortally ill. It is a 'sickness unto death' from which there is no release because a person is not able to die. This reminds us of the suicide problem, which is the ultimate negation of the will for life and is rejected as morally irresponsible by major world religions and most of the secular philosophies.

For the famous existentialist philosopher Martin Heidegger (1889-1976), death is also an extreme existential phenomenon. Since his interpretation of the mode of being as da-sein, in translation 'being-in-the-world' (bound by the historical actual being), no one can think of death in abstract terms. Death is an existential possibility of no longer being able to be there (Heidegger in Cutter 2019: 125-126). In other words, everyone has to face death in one's personal existential inevitability of dying, which makes dying extremely difficult and much more severe than the reality of death itself.

This discussion on existential despair and death leads us naturally to reflection on the fear of death and fear of the uncertainty of the unknown in death.

\section{Fear of Death}

When we say 'fear of death' what are we speaking about? Epicurus claimed that there was nothing to fear in death, because in death there are no emotions and therefore no fear. He emphasized a rational approach to understanding what hap- 
pens at death. The threat of permanent non-existence is closer every day, but in reality, it never reaches me, as Epicurus explained: 'when death is present we are not' (Heidegger in Cutter 2019: 303).

The famous actor and director Woody Allen once said, 'I am not afraid of death. I just don't want to be there when it happens' (Allen 1975). In Epicurean terms, he affirms the fear of death, but the paradox is that when death comes, there will no more, and anxiety seems to be meaningless and unnecessary.

Is there any reason to fear death? Is death unfortunate for those deceased? Dying is terrible because it irreversibly deprives the deceased of the goods of life (Thomas Nagel, quoted in Sider 2013: 160). But how can death be harmful when in death there are no properties at all? 'The dead do not exist, it is said, and so do not have any properties at all, not even the property of being deprived of the goods of life' (Sider 2013: 160). If this is true, there is an ambiguity about the goodness or badness of death. We are not sure if death is something beneficial or harmful. Epicurus seems, after all, to be right in his assessment of the futile fear of death. There is one more example of the possible benevolence of death.

Rimpoche Nawang Gehlek (1939-2017), as a Tibetan Buddhist monk, in his Good Life, Good Death, explains how death or fear of death can be transformed into something useful and beneficial:

Death is definite, as we know... Instead of running away from the thought of death, we have a better chance of doing something for ourselves if we take a look at what's coming or at least try to imagine it. Not only will this help reduce our fear, it will lay the groundwork for us to take advantage of the opportunity to transform the dying process into a process of enlightenment (Gehlek 2001: 145).

Gehlek invites us to look at the bigger picture of life and death. Our conscious decision to face death without fear, with the deep expectation of something beneficial and enjoyable, can totally transform us into better persons here and now. This is an excellent advantage of believing in benevolent death.

Hence, fear of death is the result of the unknown that follows physical and psychological existence. But the fear of death can be overcome through the belief systems, as Kelvin Chin affirms in his Overcoming the Fear of Death (Chin 2016). Most belief systems are based on the traditional ideas of life beyond the grave, and present death as a positive transition. Chin explains that, depending on one's belief system, there are ontological and psychological reasons not to fear death. 


\section{Life Beyond Death in Philosophy and Religion}

The positiveness of death is confirmed through the concept of homecoming at death. Death becomes the escape from everyday troubles and trials of life, including the very last and often intense suffering of dying. There are, of course, different theories and philosophies concerning the life beyond death or the possibility of immortality.

Greek philosophy, for example, spearheaded by the legendary Plato, speculated about the separation of body and soul at death. According to Plato, 'death is marked by the separation of the soul from the body, the soul is judged according to how one leads one's life, and the "unjust" souls "descend" to a new existence on earth' (Cutter 2019:61). Immortality of the soul became hugely influential later in nascent Christian theology, and in the form of Christianized pagan philosophy it was transformed into one of the eschatological destinies of the individual and the Church.

Greeks, of course, borrowed the concept of immortality and partial reincarnation from the East. Katha Upanishad, one of the sacred writings of Hinduism, explains the destiny of human souls that do not achieve the experience of atman ('ultimate self') before death: 'Some to the womb return — embodied souls, to receive another body; others pass into a lifeless stone (sthanu), in accordance with their works (karma), in accordance with the tradition they heard (sruta)' (Katha Upanishad v:7). For those who achieve 'ultimate self' (atman) the destiny merges with brahman (pure Being). But if the atman does not achieve ultimate enlightenment, the fate is recurrent reincarnation.

The concept of resurrection was also prevalent in the ancient world among Egyptians, Babylonians, and of course, Israelites. Continued life through bodily presence beyond death was the core of all Abrahamic covenantal religions: Judaism, Islam, and of course, Christianity.

The positiveness of death, therefore, can be expressed through faith in the bliss beyond the grave. Something better is coming. Immortality of the soul, reincarnation, or resurrection are the expressions of this positive transformation beyond this painful existence and fear of death. However, I would like to end this section with one of the secular feelings of the positive aspect of death. In this philosophy, if life was intense enough, death is bliss, even though there is nothing beyond the physical disintegration in death:

If one lives intensely, the time comes when sleep means bliss. If one loves intensely, the time comes when death seems bliss... The life I want is a life I could not endure in eternity. It is a life of love and intensity, suffering and creation that makes life worthwhile and death welcome (Kaufman 1963). 
This profound statement might be evaluated from a religious or Christian perspective. However, I will leave it as a testimony of those who do not believe in God and still affirm the positive aspects of death.

\section{Holy Scripture and Death}

In the Holy Scriptures of the Old Testament, the Hebrew word gawa is used to describe death. It means 'to expire, to breathe one's last' (Ferguson 1996: 154). In the Bible, death is more than just disintegration of physical life; it is the divine call to return to dust as the spirit goes back to God who gave it (Gen 2:7 and Eccl 12:7). The New Testament uses many figurative expressions for death, of which the most famous is sleep (John 11:13 and Acts 7:60). Moreover, death as a reality can be overcome in triumph through belief in Christ, as the only way to immortality and life beyond death (1 Cor 15). The Greek concept of immortality and the Eastern concept of reincarnation do not take seriously the phenomenon of death. Death is only a transition to immediate bliss beyond the grave. Holy Scripture, however, while it affirms that mortality is inevitable and universal, also discovers the origin of death in the sinful rebellion of humankind (Gen 2-3) and the solution for death through faith in God through Christ's atoning work of salvation (Rom $3)$. Christ is the antidote for sin and its result, destruction in death.

The testimony of sacred Christian writings show that 'the early Church lived in the consciousness of both the tragedy and mortality of human physical existence and the victory of Christ over death in which Christians shared' (Davis 1984: 300). Therefore, death could be the open door for eternal life, and death is not viewed as the final destiny of humanity. Christian hope and response to the finality of death was and is based on the testimony about the final resurrection of the dead (see Acts 13: 34-37; 17: 32; $26: 8$ etc.).

There is an evident tension between the tragedy, inevitability, and universality of death on one side, and the possibility of hope on the other. Christian faith always believes in the glorious victory of the resurrected Messiah and his atoning and intercessory role as a final solution for this tension. Therefore, Christians boldly affirm the reality of death and its sting. Still, they also look forward, beyond the inevitable end, to the resurrection and the restoration of the original purpose and meaning of human existence, a life of eternal bliss in constant communion with the Creator. The uncertainty of life and the fearful expectation of death is always counterweighted with the certainty of God's promise and action firmly grounded in his eternal Love. 


\section{Literature}

Allen, Woody, 1975, viewed 26 February 2020, from https://www.brainyquote.com/ quotes/woody_allen_138146.

Beauvoir, Simone de, 2019, A very easy death, quoted in Mary Ann G. Cutter, ed., Death: A Reader, University of Notre Dame Press, Notre Dame, IN.

Belking, Gary, 2003, 'Brain death and the historical understanding of bioethics,' Journal of the History of Medicine and Allied Sciences, 58(3), 325-361.

Cutter, Mary Ann G., 2019, Death: A reader, University of Notre Dame Press, Notre Dame, IN.

Davis, P. H., 1984, 'Death,' in Walter A. Elwell, ed., Evangelical dictionary of theology, Baker Books, Grand Rapids, MI.

Felman, Fred, 2013, 'Death and the disintegration of personality,' pp. 60-79 in Ben Bradley, ed., The Oxford handbook of philosophy of death, pp. 60-79, Oxford University Press, Oxford.

Ferguson, Paul, 1996, 'Death, mortality,' in Walter A. Elwell, ed., Evangelical dictionary of biblical theology, Baker Books, Grand Rapids, MI.

Gehlek, Rimpoche Nawang, 2001, Good life, good death, Riverhead Books, New York.

Gilmore, Cody, 2013, 'When do things die?' in Ben Bradley, ed., The Oxford handbook of philosophy of death, pp. 5-59, Oxford University Press, Oxford.

Gordon-Roth, Jessica, 2020, 'Locke on personal identity,' The Stanford Encyclopedia of Philosophy, viewed 26 February 2020, from https://plato.stanford.edu/archives/ spr2020/entries/locke-personal-identity/.

Heidegger, Martin, 1927, Being and time, quoted in Mary Ann G. Cutter, 2019, Death: A reader, University of Notre Dame Press, Notre Dame, IN.

Katha Upanishad, viewed 26 February 2020, from http://www.mountainman.com.au/katha_up.html.

Kaufman, Frederick, 1963, cited in John Martin Fischer, 2013, 'Immortality,' The Oxford handbook of philosophy of death, Oxford University Press, Oxford.

Kierkegaard, Søren, 1849, 'Despair is the sickness unto death,' in The sickness unto death, viewed 26 February, 2020, from https://www.religion-online.org/book-chapter/chapter-1-that-despair-is-the-sickness-unto-death/.

Nagel, Thomas, quoted in Theodore Sider, 2013, 'The evil of death: What can metaphysics contribute?' in Ben Bradley, ed. The Oxford handbook of philosophy of death, pp. 155-166, Oxford University Press, Oxford.

President's Commission for the Study of Ethical Problems in Medicine and Biomedical and Behavioral Research, 1981, Defining death: Medical, legal and ethical issues in the determination of death, viewed 26 February 2020, from https://scholarworks.iupui.edu/bitstream/handle/1805/707/Definining\%20death\%20-\%20 1981.pdf.

Sider, Theodore, 2013, 'The evil of death: what can metaphysics contribute?' in Ben Bradley, ed., The Oxford handbook of philosophy of death, pp. 155-166, Oxford University Press, Oxford. 


\begin{abstract}
Aleksandar S. Santrač
North-West University, Južna Afrika

Teološka škola Greenwich, Velika Britanija

Chesapeake Konferencija, Maryland, SAD

alex.santrac@gmail.com
\end{abstract}

\title{
NEIZVESNOST I SMRT - NEIZBEŽNOST, UNIVERZALNOST I NEPOVRATNOST SMRTI -
}

\begin{abstract}
Rezime
Glavna svrha ovog članka je da prikaže nesigurnost u svetlu smrti kao neophodno premošćavanje između sekularnog i hrišćanskog shvatanja smrti. Članak opisuje realnost smrti u filozofskom, i kratko u hrišćanskom smislu, u sažetom sinopsisu na kraju.
\end{abstract}

Ključne reči: smrt, hrišćanstvo, neizvesnost, očaj, strah, sveti spisi 